\title{
Studies on Weed Dynamics, Yield and Economics of Short Duration Pigeonpea (Cajanus cajan (L) Millsp.) as Influenced by Date of Sowing and Weed Management Practices
}

\author{
N.R. Sandya* and R.S. Singh \\ Department of Agronomy, Institute of Agricultural Sciences, \\ Banaras Hindu University, Varanasi, India \\ *Corresponding author
}

\section{Keywords \\ Pigeonpea, Date of sowing, Weed management, Yield, \\ Economics, Net returns, B: C}

Article Info

Accepted:

26 April 2018

Available Online:

10 May 2018

\section{A B S T R A C T}

A field experiment was conducted during rainy season of 2015 and 2016 at the Research Farm, Institute of Agricultural Sciences, BHU, Varanasi in sandy clay loam soil to find out the influence of date of sowing ( $D_{1}-11$ June, $D_{2}-25$ June and $D_{3}-9$ July) and weed management practices $\left(\mathrm{W}_{1}\right.$ - Weedy check, $\mathrm{W}_{2}$ - Pendimethalin@1.0 kg a.i. ha ${ }^{-1}$ (preemergence) $f b$ one hand weeding at 25 DAS, $\mathrm{W}_{3}$ - Pendimethalin @ $1.0 \mathrm{~kg}$ a.i. $\mathrm{ha}^{-1} \mathrm{fb}$ Imazethapyr @100 g a.i. ha ${ }^{-1}$ (post-emergence), $\mathrm{W}_{4}$ - Pendimethalin @1.0 kg a.i. ha ${ }^{-1} \mathrm{fb}$ Imazethapyr @100 g a.i. ha ${ }^{-1} f b$ one hand weeding at 50 DAS, $\mathrm{W}_{5}$ - Imazethapyr @100 g a.i. ha ${ }^{-1} f b$ one hand weeding at 50 DAS, $\mathrm{W}_{6^{-}}$Two hand weedings at 25 and 50 DAS) in pigeonpea. Results revealed that density and biomass of weeds increased with delay in sowing time from 11 June to 9 July. Eventually, minimum weed loss of $13.42 \%$ and 12.68 $\%$ was observed with $\mathrm{D}_{1}-11$ June. Among weed management practices, minimum values of number of weeds and their dry weight $\mathrm{m}^{-2}$ which was significantly lower than other weed management practices were recorded with two hand weeding at 25 and 50 DAS which is at par with Pendimethalin @ $1.0 \mathrm{~kg}$ a.i. ha ${ }^{-1} \mathrm{fb}$ Imazethapyr @ $100 \mathrm{~g}$ a.i. ha ${ }^{-1}$ at 25 DAS $f b$ one hand weeding at 50 DAS during both the years of experimentation. Minimum weed loss of $2.89 \%$ and $2.41 \%$ was observed with was recorded with $\mathrm{W}_{4}$. Yield, Gross returns and Net returns, B: C ratio of pigeonpea were superior when crop was sown on 11 June compared to delay in sowings during both the years. Among weed control treatments, two hand weeding at 25 and 50 DAS which is at par with Pendimethalin @ $1.0 \mathrm{~kg}$ a.i. ha ${ }^{-1}$ $f b$ Imazethapyr @ $100 \mathrm{~g}$ a.i. ha ${ }^{-1}$ at 25 DAS $f b$ one hand weeding at 50 DAS with respect to Yield, Gross returns and Net returns but higher B: C ratio was recorded with Pendimethalin@1.0 kg a.i. ha ${ }^{-1} f b$ Imazethapyr @ $100 \mathrm{~g}$ a.i. ha ${ }^{-1}$ at 25 DAS

\section{Introduction}

Pigeonpea [Cajanus cajan (L.) Millspaugh] is an important legume crop of the semi-arid tropics of Asia, Africa and Latin America. It is high in protein (21-25\%) and several essential amino acids (Saxena et al., 2010). Pigeonpea is the second most important pulse crop of India after chickpea. India has the largest acreage under pigeonpea (4.05 $\mathrm{m} \mathrm{ha})$ with a total production and productivity of $3.27 \mathrm{mt}$ and $799 \mathrm{~kg} \mathrm{ha}^{-1}$, respectively. The increase in area cultivated under pigeonpea, production and productivity from $1970-71$ to $2012-13$ is 
$43 \%$ (2.66 $\mathrm{m}$ ha to $3.81 \mathrm{~m} \mathrm{ha}), 60.6 \%$ and $13.7 \%$, respectively (AICRPP, 2016). The increasing trend of area cultivated under pigeonpea has been noticed from 1970-71 to 2012-13 in states like Andhra Pradesh by $142.2 \%$, Karnataka by $115.5 \%$, Odisha by $175.2 \%$, Maharashtra by $69 \%$ and Gujarat by $165.1 \%$ due to hike in using short duration and medium duration pigeonpea varieties. Pigeonpea is the most preferable crop of rainfed areas because of its well-developed tap root system as well as lateral root system, its ability to extract moisture from deeper soil layers made short duration pigeonpea variety a preferable option even in moisture stress conditions which might be the probable reason for increase in area cultivated under pigeonpea in these areas. In states like Punjab and Haryana, cultivation of short duration pigeonpea varieties shown increasing trend of an area, production, and productivity. In Haryana, the increase in area cultivated under pigeonpea is $46 \%$, production and productivity are by $233.3 \%$ and $128 \%$, respectively from 1970-71 to 2012-13 (AICRPP, 2014). It leads to follow pigeonpea-wheat cropping system under assured irrigation facilities. Time of sowing, a non-monetary input, has a considerable influence on growth and yield of this crop. It ensures the complete harmony between vegetative and reproductive phases on one hand and climatic rhythm on the other hand. Sole pigeonpea gets heavily infested with weeds due to wide row and plant to plant spacing, slow early growth of crop and frequent rains and inadequate sunlight during kharif season. In realizing the yield potential of the crop, sound weed management practices becomes imperative as the weeds start competing fiercely for moisture, nutrients and space with the crop right from the sowing of the crop. Weeds pose a major problem to its productivity which may lead to its yield reduction from $68-80 \%$ (Talnikar et al., 2008). The critical period is during the first eight weeks after sowing. Keeping all these facts in view, the present study entitled "Studies on weed dynamics, Yield and Economics of short duration pigeonpea (Cajanus cajan (L) Millsp.) as influenced by date of sowing and weed management practices" is thus investigated.

\section{Materials and Methods}

A field experiment was conducted during rainy season of 2015 and 2016 at the Research Farm, Institute of Agricultural Sciences, BHU, Varanasi in sandy clay loam soil. The soil of the experimental field was sandy clay loam texture with $\mathrm{pH}$ 7.46. It was moderately fertile being low in organic carbon $(0.44 \%)$, available nitrogen $\left(186.38 \mathrm{~kg} \mathrm{~N} \mathrm{ha}^{-1}\right)$, and medium in available phosphorus $(18.26 \mathrm{~kg}$ $\mathrm{P}_{2} \mathrm{O}_{5} \mathrm{ha}^{-1}$ ), potassium (205.30 kg K $\mathrm{O} \mathrm{ha}^{-1}$ ) and sulphur (19.30 kg S ha ${ }^{-1}$ ). The experiment was laid out in split plot design with three replications. Seeds were sown at the rate of 20 $\mathrm{kg} \mathrm{ha}{ }^{-1}$ with spacing of $60 \mathrm{~cm} \mathrm{x} 20 \mathrm{~cm}$. Experiment was conducted under rainfed conditions but with pre sowing irrigation during both the years. Three different date of sowing are $\mathrm{D}_{1}$-June $11, \mathrm{D}_{2}$-June $25, \mathrm{D}_{3}$-July 09 were allotted to main plots and six treatments (weed management practices) were taken in subplots. They are $\mathrm{W}_{1}$ - Weedy check, $\mathrm{W}_{2}$ - Pendimethalin @ $1.0 \mathrm{~kg}$ a.i. ha ${ }^{-1}$ (preemergence) $f b$ one hand weeding at 25 DAS, $\mathrm{W}_{3^{-}}$Pendimethalin @ $1.0 \mathrm{~kg}$ a.i. $\mathrm{ha}^{-1} \mathrm{fb}$ Imazethapyr @ $100 \mathrm{~g}$ a.i. ha ${ }^{-1}$ (postemergence), $\mathrm{W}_{4}$ - Pendimethalin @1.0 kg a.i. $\mathrm{ha}^{-1} f b$ Imazethapyr @ $100 \mathrm{~g}$ a.i. ha ${ }^{-1} f b$ one hand weeding at 50 DAS, W5 - Imazethapyr @ $100 \mathrm{~g}$ a.i. $\mathrm{ha}^{-1} \mathrm{fb}$ one hand weeding at $50 \mathrm{DAS}$, $\mathrm{W}_{6^{-}}$Two hand weedings at 25 and 50 DAS. There are 18 ttreatment combinations with total, 54 number of plots. The pigeonpea cv. UPAS-120, short duration variety was used in the experiment. The recommended dose of 20 $\mathrm{kg} \mathrm{N} \mathrm{ha}{ }^{-1}, 40 \mathrm{~kg} \mathrm{P}_{2} \mathrm{O}_{5} \mathrm{ha}^{-1} 20 \mathrm{~kg} \mathrm{~K}_{2} \mathrm{O}$ and 30 $\mathrm{kg} \mathrm{S} \mathrm{ha}^{-1}$ in the form of urea, SSP and MOP respectively were applied. The plot size was 
$4.8 \mathrm{~m}$ x $5.0 \mathrm{~m}$ accommodating 8 rows per plot. Herbicides were applied by a knapsack sprayer fitted with a flat fan nozzle with a volume rate of 500 liter/ha.

The crop was raised with all other recommended package of practices required. Density and biomass of the total weeds and yield were recorded at harvest during both the years. The data were analyzed as per the standard procedure for "Analysis of Variance" (ANOVA) as described by Gomez and Gomez (1984).

The number of weeds were counted from an area of $0.5 \times 0.5 \mathrm{~m}=0.25 \mathrm{~m} 2$ (quadrant size) in net plot of each treatment that was randomly selected and converted to per square meter $\left(\mathrm{m}^{-2}\right)$ basis. From the quadrant, weeds were removed, counted and recorded. Later the original values were transformed to square root values $(\sqrt{ } \mathrm{X}+0.5)$ and subjected to statistical analysis. The weeds present within the quadrant area were uprooted, and transferred to brown covers. After air drying, the weeds were dried in the hot air oven at 65$70^{\circ} \mathrm{C}$ till the constant weights obtained and the original data were subjected to square root transformation $(\sqrt{ } \mathrm{X}+0.5)$ and analysed statistically.

Weed index is reduction in yield due to weed infestation. It is calculated by using the formula given by Gill and Kumar (1969).

Yield of weed free plot - Yield of treated plot $\mathrm{WI}=$ $\mathrm{x} 100$

Yield of weed free plot

\section{Results and Discussion}

\section{Weed flora}

There were preedominantly fifteen weed species identified in the experimental field during both the years. Among grasses,
Cynodon dactylon, Digitaria sanguinalis, Dactyloctenium aegypticum were the predominant weeds. Among sedges, Cyperus rotundus and Cyperus iria were most dominant. In broad leaved weeds, Commelina benghalensis, Parthenium hysterophorus, Euphorbia hirta, Cleome viscose and Caesulia axillaris were dominant weed flora.

\section{Weed density and weed drymatter}

Different date of sowing showed marked difference on weed density and weed dry matter at different growth stages. Density and biomass of weeds increased significantly with corresponding delay in each date of sowing (Table 1). Sowing of pigeonpea on June 11 $\left(D_{1}\right)$ was significantly more competitive than $D_{2}$ and $D_{3}$ with respect to reduction of weed density and weed dry matter along with minimum weed loss of $13.42 \%$ and $12.68 \%$ during both the years. Delay in sowing upto $\mathrm{D}_{3}$ significantly increased the values of weed growth parameters viz. number of weeds $\mathrm{m}^{-2}$ and dry weight of weeds $\mathrm{m}^{-2}$ during both the years.

Among weed management practices, minimum values of number of weeds and their dry weight $\mathrm{m}^{-2}$ which was significantly lower than other weed management practices were recorded with two hand weeding at 25 and 50 DAS which is at par with Pendimethalin@ $1.0 \mathrm{~kg}$ a.i. $\mathrm{ha}^{-1} \mathrm{fb}$ Imazethapyr @ $100 \mathrm{~g}$ a.i. ha $^{-1}$ at 25 DAS $f b$ one hand weeding at 50 DAS during both the years of experimentation. Minimum weed loss of 2.89 $\%$ and $2.41 \%$ was observed with was recorded with $\mathrm{W}_{4}$.

All weed management practices recorded significantly lower values of all weeds parameters over weedy check in both the years. These results are in accordance with Malik and Yadav (2014) and Upadhyay (2002). 
Table.1 Effect of date of sowing and weed management practices on number of weeds $\mathrm{m}^{-2}$, dry weight of weeds $\mathrm{m}^{-2}$ and weed index $(\%)$ in pigeonpea

\begin{tabular}{|c|c|c|c|c|c|c|c|}
\hline \multirow{2}{*}{\multicolumn{2}{|c|}{ Treatment }} & \multicolumn{2}{|c|}{ Number of weeds $\mathrm{m}^{-2}$} & \multicolumn{2}{|c|}{ Dry weight of weeds $\mathrm{m}^{-2}$} & \multicolumn{2}{|c|}{ Weed Index (\%) } \\
\hline & & 2015 & 2016 & 2015 & 2016 & 2015 & 2016 \\
\hline \multicolumn{8}{|c|}{ A. Date of sowing } \\
\hline $\mathbf{D}_{1}$ & June 11 & $\begin{array}{c}11.87 \\
(146.75)\end{array}$ & $\begin{array}{c}11.62 \\
(140.32)\end{array}$ & $\begin{array}{c}10.48 \\
(114.85)\end{array}$ & $\begin{array}{c}10.26 \\
(110.34)\end{array}$ & 13.42 & 12.68 \\
\hline $\mathbf{D}_{2}$ & June 25 & $\begin{array}{c}13.27 \\
(183.28)\end{array}$ & $\begin{array}{c}12.94 \\
(173.79)\end{array}$ & $\begin{array}{l}11.97 \\
(149)\end{array}$ & $\begin{array}{c}11.66 \\
(141.69)\end{array}$ & 14.85 & 14.19 \\
\hline $\mathbf{D}_{3}$ & July 09 & $\begin{array}{l}15.08 \\
(237)\end{array}$ & $\begin{array}{c}14.65 \\
(223.46)\end{array}$ & $\begin{array}{c}13.31 \\
(184.21)\end{array}$ & $\begin{array}{c}13.03 \\
(176.55)\end{array}$ & 16.94 & 16.27 \\
\hline \multicolumn{2}{|c|}{ SEm \pm} & 0.50 & 0.47 & 0.42 & 0.40 & - & - \\
\hline \multicolumn{2}{|c|}{$\mathrm{CD}(\mathrm{P}=0.05)$} & 1.95 & 1.82 & 1.64 & 1.59 & - & - \\
\hline \multicolumn{8}{|c|}{ B. Weed management practices } \\
\hline $\mathrm{W}_{1}$ & Weedy Check & $\begin{array}{c}18.99 \\
(363.91)\end{array}$ & $\begin{array}{c}18.37 \\
(340.57)\end{array}$ & $\begin{array}{c}16.71 \\
(281.39)\end{array}$ & $\begin{array}{c}16.37 \\
(269.7)\end{array}$ & 36.87 & 34.69 \\
\hline$\overline{W_{2}}$ & Pendimethalin $f b$ one $\mathrm{HW}$ at $25 \mathrm{DAS}$ & $\begin{array}{c}14.37 \\
(207.31)\end{array}$ & $\begin{array}{c}13.91 \\
(194.2)\end{array}$ & $\begin{array}{c}13.02 \\
(170.4)\end{array}$ & $\begin{array}{c}12.83 \\
(165.52)\end{array}$ & 23.74 & 21.54 \\
\hline$\overline{\mathrm{W}_{3}}$ & Pendimethalin $f b$ Imazethapyr & $\begin{array}{c}13.2 \\
(175.62)\end{array}$ & $\begin{array}{c}12.93 \\
(168.18)\end{array}$ & $\begin{array}{c}12.05 \\
(145.28)\end{array}$ & $\begin{array}{c}11.76 \\
(138.41)\end{array}$ & 13.00 & 12.02 \\
\hline $\mathrm{W}_{4}$ & Pendi $f b$ Imaz $f b$ one HW at 50 DAS & $\begin{array}{c}11.22 \\
(126.29)\end{array}$ & $\begin{array}{c}10.97 \\
(120.55)\end{array}$ & $\begin{array}{c}9.64 \\
(93.72)\end{array}$ & $\begin{array}{c}9.39 \\
(89.02)\end{array}$ & 2.89 & 2.41 \\
\hline$\overline{W_{5}}$ & Imazethapyr $f b$ one HW at 50 DAS & $\begin{array}{c}12.45 \\
(155.87)\end{array}$ & $\begin{array}{c}12.2 \\
(149.93)\end{array}$ & $\begin{array}{c}11.05 \\
(123.02)\end{array}$ & $\begin{array}{c}10.8 \\
(117.43)\end{array}$ & 10.88 & 9.67 \\
\hline $\mathrm{W}_{6}$ & Two HW at 25 DAS and 50 DAS & $\begin{array}{c}10.21 \\
(105.06)\end{array}$ & $\begin{array}{c}10.04 \\
(101.71)\end{array}$ & $\begin{array}{c}9.04 \\
(82.3)\end{array}$ & $\begin{array}{c}8.74 \\
(77.08)\end{array}$ & 0.0 & 0.0 \\
\hline \multicolumn{2}{|c|}{$\mathrm{SEm} \pm$} & 0.38 & 0.39 & 0.63 & 0.60 & - & - \\
\hline \multicolumn{2}{|c|}{$\mathrm{CD}(\mathrm{P}=0.05)$} & 1.09 & 1.12 & 1.81 & 1.72 & - & - \\
\hline
\end{tabular}


Table. 2 Effect of date of sowing and weed management practices on cost of cultivation $\left(\right.$ Rs ha $\left.^{-1}\right)$, gross return $\left(\right.$ Rs ha $\left.{ }^{-1}\right)$, net return $\left(\mathrm{Rs} \mathrm{ha}^{-1}\right.$ ) and B: C ratio

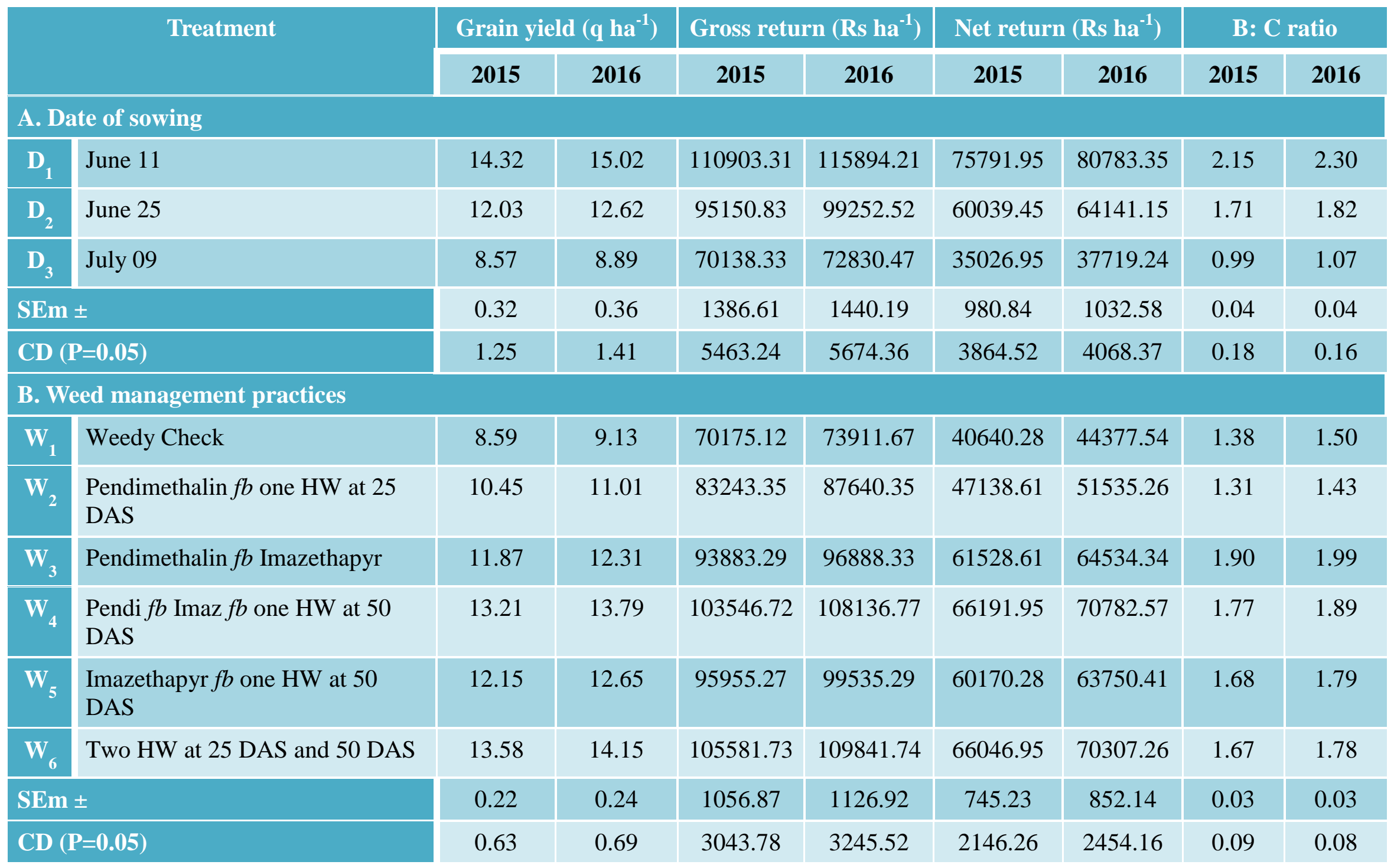




\section{Yield}

Sowing of pigeonpea on June $11 \quad\left(D_{1}\right)$ significantly caused marked improvement in grain yield over later sowings of pigeonpea, $\mathrm{D}_{2}$ and $\mathrm{D}_{3}$ (Table 2). Early sowing provided better vigor to crop and it also encountered less weed competition consequently resulting into higher productivity. Similar findings were reported with Ram et al., 2011 and Singh and Srivastava, 2002

All the weed management practices were found significantly superior over weedy check with respect to grain yield. Among weed management practices, two hand weedings at 25 and 50 DAS and Pendimethalin @ $1.0 \mathrm{~kg}$ a.i. ha ${ }^{-1} f b$ Imazethapyr @ 100 g a.i. ha ${ }^{-1}$ at 25 DAS $f b$ one hand weeding at 50 DAS recorded maximum yields which was at par with each other and significantly superior to rest of the treatments during both the years. Lower weed infestation and better plant growth in the above treatments might have lead to higher yield. These findings are in similar lines with Reddy et al., 2016 Samant, 2015 and Singh et al., 2010.

\section{Economics}

Sowing of pigeonpea during $24^{\text {th }}$ standard week, June 11-17 $\left(D_{1}\right)$ recorded significantly higher gross return, net return and $\mathrm{B}$ : $\mathrm{C}$ ratio during both the years of experimentation (Table 2). Among weed management practices, $\mathrm{W}_{6}$ (two hand weeding at 25 and 50 DAS) recorded maximum gross return which was significantly superior to rest of the treatments during both the years but was statistically at par with $\mathrm{W}_{4}$ (Pendimethalin @ $1.0 \mathrm{~kg}$ a.i. $\mathrm{ha}^{-1} \mathrm{fb}$ Imazethapyr @ $100 \mathrm{~g}$ a.i. ha ${ }^{1}$ at 25 DAS $f b$ one hand weeding at 50 DAS). $\mathrm{W}_{4}$ recorded maximum net return which was statistically at par with $\mathrm{W}_{6}$ but remained significantly superior to rest of the treatments during both the years, whereas, $\mathrm{W}_{3}$
(Pendimethalin $f b$ Imazethapyr) recorded significantly maximum B: $\mathrm{C}$ ratio and it was followed by $\mathrm{W}_{4}$ during both the years. Weedy check recorded significantly minimum gross return, net return and $\mathrm{B}$ : $\mathrm{C}$ ratio during both the years of study. These studies are in similarities with Samant (2015).

Short duration pigeonpea crop should be sown on June 11 for yield and returns. Though treatments like two hand weedings at 25 and 50 DAS, Pendimethalin @ $1.0 \mathrm{~kg}$ a.i. $\mathrm{ha}^{-1} \mathrm{fb}$ Imazethapyr @ $100 \mathrm{~g}$ a.i. $\mathrm{ha}^{-1}$ at 25 DAS $f b$ one hand weeding at 50 DAS was found most effective in controlling weeds and enhancing pigeonpea yield, Pendimethalin at $1.0 \mathrm{~kg} \mathrm{ha}^{-1} \mathrm{fb}$ Imazethapyr was better weed management practice with respect to profitability of the crop.

\section{References}

Annual Report, All India Co-ordinated research project on pigeonpea, Indian Institute of Pulses Research, Kanpur, 97, 2016.

Annual Report, All India co-ordinated Research Project on pigeonpea, Indian Institute of Pulses Research, Kanpur, III $\& 24,2014$.

Gill, GS and Vijaya Kumar, K. Weed IndexA New Method of Reporting Weed Control Trials. Indian Journal of Agronomy, 14, 96-98, 1969.

Gomez, K.A. and Gomez, A.A. (1984). Statistical procedure for agricultural research, 2nd ed. John Willey \& Sons, New York, U.S.A. pp. 241-271.

Malik, RS and Yadav, A, Effect of sowing time and weed management on performance of pigeonpea, Indian Journal of Weed Science, 46(2), 132134, 2014.

Ram, H., Singh, G., Sekhon, H.S. and Khanna, V. 2011. Effect of sowing time on the performance of pigeonpea 
genotypes. Journal of Food Legumes. 24(3): 207-210.

Reddy, AS, Rao, PV, Babu, JS and Rao, YK, Response of integrated weed management practices on growth and yield of pigeonpea, International Journal of Current Microbiology and Applied Sciences, 5(3), 610-616, 2016.

Samant, TK, Effect of weed management practices on weed dynamics and growth, yield, economics of pigeonpea under rainfed condition, Advance Research Journal of Crop Improvement, 6(2), 94-99, 2015.

Saxena, K.B. and Nadarajan, N. 2010. Prospects of pigeonpea hybrids in Indian agriculture. Elec. J. Plant Breed. 1:1107-1117.

Singh, G. and Sekhon, H.S. 2013. Integrated weed management in pigeonpea. World Journal of Agricultural Sciences. 9 (1): 86-91.
Singh, G., Aggarwal, N. and Ram, H. 2010. Effect of row spacing and weed management practices on weeds, growth and yield of pigeonpea. Indian Journal of weed Sciences. 42 (3 \& 4): 241-243.

Singh, JP and Srivastava, SK, Effect of sowing time and row spacing on the performance of early maturing pigeonpea, Progressive Agriculture, 2(1), 96-97, 2002.

Talnikar, A.S., Kadam, D.R., Karande, D.R. and Jogdand, P.B. 2008. Integrated weed management in pigeonpea. International Journal of Agricultural Sciences. 4: 363-370.

Upadhyay, VB, Effect of sowing dates and weed control methods on weed management and productivity of pigeonpea [Cajanus cajan (L.) Millsp.] in M.P, Indian Journal of Weed Science, 34(3\&4), 301-302, 2002.

\section{How to cite this article:}

Sandya, N.R. and Singh, R.S. 2018. Studies on Weed Dynamics, Yield and Economics of Short Duration Pigeonpea (Cajanus cajan (L) Millsp.) as Influenced by Date of Sowing and Weed Management Practices. Int.J.Curr.Microbiol.App.Sci. 7(05): 3655-3661. doi: https://doi.org/10.20546/ijcmas.2018.705.421 